\title{
BEHAVIOR UNDER SOCIAL PRESSURE: EMPTY ITALIAN STADIUMS AND REFEREE BIAS
}

\author{
PER PETTERSSON-LIDBOM \\ MIKAEL PRIKS
}

CESIFO WORKING PAPER NO. 1960

CATEGORY 4: LABOUR MARKETS

APRIL 2007

An electronic version of the paper may be downloaded

- from the SSRN website:

- from the RePEc website:

www.SSRN.com

- from the CESifo website:

www.RePEc.org

www.CESifo-group.de 


\title{
BeHAVIOR UNDER SOCIAL PRESSURe: EMPTY ITALIAN STADIUMS AND REFEREE BIAS
}

\begin{abstract}
This paper studies how social pressure affects the behavior of soccer referees. We make use of an attractive source of exogenous variation in the number of spectators at matches. Due to recent hooligan violence, the Italian government has implemented a regulation that forces some soccer teams to temporarily play home matches in empty stadiums. We find that referees punish away players more harshly and home players more lightly when the games are played in front of spectators compared to when they are not. This indicates that referees exhibit home bias caused by social pressure from the spectators.
\end{abstract}

JEL Code: J00.

Keywords: social pressure, bias, incentives, personnel economics, natural experiment.

Per Pettersson-Lidbom

Department of Economics

Stockholm University

10691 Stockholm

Sweden

pp@ne.su.se
Mikael Priks

Center for Economic Studies at the

University of Munich

Schackstr. 4

80539 Munich

Germany

mikael.priks@lmu.de

April 5, 2007 


\section{Introduction}

The role of social pressure on behavior is an important element in many areas of the society (e.g., for workplace productivity, politics, the judicial system, social customs and sports). There is a voluminous theoretical literature in economics that deals with this topic (see e.g. Akerlof 1980, Bernheim 1994, and Becker and Murphy 2000) but there is considerably less empirical work. ${ }^{1}$

The contribution of this paper is to provide such evidence from the impact of spectators on the behavior of referees. We use a unique exogenous source of variation in the number of spectators due to hooligan violence in Italy on February 2, 2007. In response to the incident, the Italian minister of interior declared that spectators would only be allowed into those arenas that fulfilled certain requirements. In total, 24 games have so far been played without spectators in the Italian soccer leagues Serie A and Serie B.

Our empirical identification strategy is to compare the behavior of the same referee in games with and without spectators, i.e., we make use of referee specific-fixed effect specifications. We find large and statistically significant effects that away players received fewer punishments (i.e., fewer fouls and cards) in the games they played without spectators while the home players were often punished more harshly. This strongly suggests that pressure from the spectators affects the referees' behavior.

This paper is related to a small literature on the behavior of referees. For example, Garicano et al. (2005) and Dohmen (2005) find that referees systematically favor the home team by shortening close games where the home team is ahead, and lengthening close games where the home team is behind. ${ }^{2}$ Thanks to the exogenous source of variation in the number of spectators in the Italian soccer leagues, we believe that our research strategy adds considerably to this literature.

The rest of the paper is organized as follows. Section 2 describes the data, the source of exogenous variation, and the empirical strategy. The results are presented in Section 3 and Section 4 concludes.

\footnotetext{
${ }^{1}$ Interesting exceptions are Garicano et al. (2005), Dohmen (2005) and Sutter and Kocher (2004).

${ }^{2}$ Nevill et al. (2002) found that English referees who watched video-taped tackles with the sound from the crowd called for 15.5 percent fewer fouls for the home team compared to those that did not hear the sound.
} 


\section{Data and empirical framework}

On February 2, 2007, supporters from the Italian football clubs Calcio Catania and Palermo Calcio clashed with each other and the police in Catania in serious acts of hooligan violence. Police officer Filippo Raciti was killed and around hundred people were injured. Following the riots, the Italian government announced that the enforcement of the current football stadia act, "Decreto Pisanu”, enacted in 2005, would be radically changed. In its original form, it required Italian football clubs to meet specific safety standards in their stadiums. However, with the indulgence of the government, these standards have been ignored by most of Serie A and Serie B clubs, and virtually all games have been played in front of spectators. Following the events in Catania, the government altered its position and forced the clubs that had stadiums with deficient safety standards to play their home games without spectators.

We will use the drastically tightened enforcement of the football stadia act as an exogenous variation in the number of spectators to evaluate the hypothesis that referees may be biased due to social pressure. We use data from serie A and serie B for the season 2006/2007, which altogether consists of 842 games. ${ }^{3}$ Currently, 24 games have been played without spectators due to the inability to comply with the act. Apart from Calcio Catania and Brescia Calcio, all teams are now allowed to have spectators again. ${ }^{4}$ Table 1 shows the games that have been played without spectators.

Referees control the games by having the possibility to adjudicate fouls, yellow cards, and red cards. Committing a foul implies that the opposing team gets possession of the ball. ${ }^{5}$ If one player receives two yellow cards, or one instant red card, then he is sent off the pitch. This implies that his team has to play one man short, which is a significant disadvantage. ${ }^{6}$ So far, 41 different individuals have refereed games in the two leagues. 36 referees are active in both serie A and serie B and five in serie B only. The average number of games per referee is currently approximately $20 .^{7}$

\footnotetext{
${ }^{3}$ The 20 teams in serie A and the 22 teams in serie B play each other twice per year.

${ }^{4}$ Because the hooligan event took place in Catania, and because the club has not complied with safety regulation earlier, Calcio Catania has to play all of its home fixtures at a neutral venue without spectators. Due to this special regulation, and since the hooligan event may be correlated with the clubs' outcomes, we exclude this club's home games without spectators from our analysis. However, our results are not affected qualitatively by the inclusion of these games.

${ }^{5}$ If the foul is committed close the own team's penalty area, i.e., the own goal, then the free kick that follows gives the opposing team an excellent opportunity to score.

${ }^{6}$ He may also be suspended for games in the future. This, however, does not affect the number of players on the pitch.

${ }^{7}$ Referees are appointed on the Friday before the games are played. The salary is 70000 euro per year or 35000 per year depending on experience. The referees additionally receive 3500 euro per game in serie A and 2000 euro per game in Serie B.
} 
The data is obtained from the Italian newspaper La Gazzetta dello Sport's home page. Because the number of fouls per game differs across sources, we also use data on fouls from the home page of ESPN (the Entertainment and Sports Programming Network). Table 2 provides summary statistics for home and away teams regarding the number of fouls, the number of yellow cards, and the number of red cards.

To test whether referees are biased due to social pressure we use the following set up. Let $Y_{\mathrm{ij}}$ denote referee $i$ 's behavior in game $j$ (fouls, yellow cards, and red cards) and let no_spectators be an indicator variable for the games when the teams were forced to play without any spectators. We can now estimate the effect of having no spectators on the referee‘s behavior by running the regression

$$
Y_{i j}=\alpha_{j}+\beta \text { no_spectators }{ }_{i j}+v_{i j}
$$

where $\alpha_{j}$ is a referee fixed effect. The parameter $\beta$ measures the effect of having no spectators on the behavior of the referee. It is important to note that the parameter $\beta$ is identified only by the within referee variation since we include fixed referee effects. In other words, we compare the behavior of the same referee when he is a referee in a game with no spectators compared to a game with many thousands of spectators. ${ }^{8}$ To be able to test whether the referee is biased, we separate the behavioral response of a referee towards both the home team and the away team in games with many or with no spectators. The referee is biased if he would give the home team more punishments (e.g., fouls, yellow cards and red cards) compared to the away team in the games without spectators. In other words, we estimate separate regressions of (1) for both the home team and the away team, and define the bias of the referee as the difference between the coefficient $\beta$ for the home team, $\beta^{\text {Home }}$, and the away team, $\beta^{\text {Away }}$. Thus, the referee is biased due to social pressure if $\beta^{\text {Home }}>\beta^{\text {Away }}$ and unbiased if $\beta^{\text {Home }}=\beta^{\text {Away }}{ }^{9}$ Here, we implicitly assume that the incentives of players of both the home team and away team are affected similarly of the presence or absence of spectators and the only reasons why $\beta^{\text {Home }}>\beta^{\text {Away }}$ is because of the behavior of the referee. If players are affected by spectators,

\footnotetext{
${ }^{8}$ The average number of spectators is 18376 in serie A and 8286 in serie B.

${ }^{9}$ This approach is equivalent to a "difference-in-difference” model, i.e., $Y=\delta$ home_team $+\theta$ no_specators + $\pi$ home_team $\times$ no_spectators + referee fixed effects, where home_team is an indicator of whether the team is a home team or not. Thus, this set up consists of a group fixed effect (home_team), a treatment indicator (no_specators), and an interaction between the group and treatment indicators (home_team $\times$ no_specators) where the different-in difference parameter is $\pi=\beta^{\text {Home }}-\beta^{\text {Away }}$. This specification makes it clear that the identifying assumption is that there are no other interactions between group and treatment except for the treatment (nospectators) itself.
} 
then we find it likely that home teams play more intensively in front of spectators. Thus, if anything, our estimate of the size of the bias of the referee is likely to be underestimated.

\section{Results}

In this section we provide evidence on the behavior of Italian referees, i.e., results from estimating equation (1) for both the home and away teams. Table 3 shows the results from these regressions. Columns 1 and 2 display the results for the number of fouls. The results are striking: while the referee gives the away team 2.6 fewer fouls when there are no spectators, he gives the home team 1.7 more fouls. Thus the estimate of the referee bias is $1.7-(-2.6)=$ 4.3 fouls. This is highly statistically significant as can be seen by the $t$-test for equality of the two parameters, $\beta^{\text {Home }}=\beta^{\text {Away }}$ in the third row of the column. Since the average number of fouls is 19 per team and game, the bias effect is as high as 23 percent.

Columns 3 and 4 report the results for the number of yellow cards. Once again, we see a striking difference between a referee's behavior towards the home team and the away team in games without spectators. The referee gives somewhat fewer yellow cards to the home team $(-0.48)$ in the games without spectators compared to the games with spectators. But because they give the away team much fewer yellow cards, -1.16 , the estimate of the referee bias is $-.0 .48-(-1.16)=.68$ cards, which is statistically significant at the 5.7 percent level. In columns 5 and 6 , we present the results on the number of red cards. The differential impact on the home and away team is in line with the previous results. The referee bias is $-.06-0.13=.07$ red cards, which is statically significant at the 10 percent level. The average number of yellow and red cards is 2.62 and 0.105 respectively. The estimated referee bias therefore constitutes a 26 percent effect for yellow cards, and a 70 percent effect for red cards. Table 4 shows that these results are robust to including home team and away fixed effects. The estimated bias effect is 4.56 for fouls, 0.61 for yellow cards, and 0.07 for red cards. In fact, the results also hold without any controls (i.e., referee and team fixed effects) since the estimated bias effect is 3.96 for fouls ( $t=3.98, p$-value $=0.000), 0.63$ for yellow cards $(t=2.00, p$-value $=0.052)$, and .085 for red cards $(t=1.74, p$-value $=0.089)$. Finally, the results on referee bias do not change when serie A and serie B are studied separately as can be seen from Tables 5 and 6 respectively (the estimated effects are however less precisely measured). Taken together, the consistency of the estimated bias effect across different specifications and across different outcomes of the referee strongly suggests that the estimated referee effect is caused by social pressure from the crowd. 


\section{Conclusions}

Soccer referees are supposed to be neutral. Yet, we find evidence that Italian referees change their behavior in games played without spectators. The evidence we provide is consistent with the idea that individuals are likely to change their behavior under influence of social pressure.

An alternative explanation of our findings is that players, rather than referees, change their behavior in games without spectators. However, for this explanation to be true, home players must play less intensively in games with spectators compared to without. We find it more reasonable that home teams play more aggressively in games with spectators. Thus, we are probably understating the true referee bias effect.

Our results may have further implications outside the world of sports. For example, courts and politicians could be affected by pressure from media, which may affect their decisions. More empirical work on this topic would complement the findings in this study. 


\section{References}

Akerlof, G. (1980), “A Theory of Social Custom, of Which Unemployment May Be One Consequence,” Quarterly Journal of Economics, 94: 749-775.

Becker G., and K. Murphy (2000), Social Economics, Market Behavior in a Social Environment (Harvard University Press, Cambridge, MA).

Bernheim, D. (1994), “A Theory of Conformity,” Journal of Political Economy, 102: 841-77.

Dohmen D., (2005), "Social Pressure Influences Decisions of Individuals: Evidence from the Behavior of Football Referees,” IZA Discussion Paper no 1595.

Garicano, L., Palacios-Huerta, I., and C. Prendergast (2005), "Favoritism under Social Pressure," Review of Economics and Statistics, 87: 208.

Nevill, A., Balmer, N., and A. Williams (2002), “The Influence of Crowd Noise and Experience upon Refereeing Decisions in Football”, Psychology of Sport and Exercise, 3: 216-2727.

Sutter M., and M. Kocher (2004), “Favoritism of Agents - The Case of Referees' Home Bias,” Journal of Psychology, 25: 461-469. 
Table 1. Games without spectators

\begin{tabular}{|c|c|c|}
\hline Date & Home team & Away team \\
\hline \multicolumn{3}{|c|}{ Serie A } \\
\hline February 17 & Ascoli & Udinese \\
\hline February 11 & Atalanta & Lazio \\
\hline February 25 & Catania & Internazionale \\
\hline March 04 & Catania & Siena \\
\hline March 13 & Catania & Reggina \\
\hline February 17 & Catania & Fiorentina \\
\hline February 11 & Chievo & Internazionale \\
\hline February 17 & Empoli & AS Roma \\
\hline February 11 & Fiorentina & Udinese \\
\hline February 18 & Livorno & Messina \\
\hline February 11 & Messina & Catania \\
\hline \multicolumn{3}{|c|}{ Serie B } \\
\hline February 17 & Albinoleffe & Triestina \\
\hline March 17 & Brescia & Rimini \\
\hline February 24 & Brescia & Verona \\
\hline February 10 & Brescia & Bari \\
\hline February 10 & Lecce & Verona \\
\hline February 17 & Mantova & Lecce \\
\hline February 10 & Modena & Albinoleffe \\
\hline December 16 & Napoli $^{10}$ & Mantova \\
\hline February 10 & Napoli & Piacenza \\
\hline February 18 & Napoli & Arezzo \\
\hline February 10 & Pescara & Mantova \\
\hline February 24 & Piacenza & Genoa \\
\hline February 10 & Triestina & Treviso \\
\hline February 17 & Verona & Spezia \\
\hline
\end{tabular}

${ }^{10}$ This game was played without spectators in Perugia due to previous Napoli-related hooliganism. 
Table 2. Summary Statistics

$\begin{array}{cccc}\text { Mean } & \text { St. Dev. } & \text { Min } & \text { Max } \\ & & & \\ 19.27 & \frac{\text { Home Team }}{5.15} & 7 & 46 \\ 2.44 & 1.28 & 0 & 7 \\ 0.089 & 0.296 & 0 & 2\end{array}$

$\begin{array}{lcccc}\text { Fouls } & 19.33 & 5.23 & 7 & 49 \\ \text { Yellow Card } & 2.79 & 1.47 & 0 & 9 \\ \text { Red Card } & 0.121 & 0.342 & 0 & 2\end{array}$

Note: The information about yellow cards and the red cards is taken from Italian newspaper La Gazzetta dello Sport's home page. The information about fouls is taken from both the Italian newspaper La Gazzetta dello

Sport's home page and from the home page of ESPN (the Entertainment and Sports Programming Network). 
Table 3. Behavior of the referee regarding the away and home teams

\begin{tabular}{|c|c|c|c|c|c|c|}
\hline & \multicolumn{2}{|c|}{ Fouls } & \multicolumn{2}{|c|}{ Yellow cards } & \multicolumn{2}{|c|}{ Red cards } \\
\hline \multirow{3}{*}{ No spectators } & Home team & Away team & Home team & Away team & Home team & Away team \\
\hline & 1.74 & -2.62 & -.48 & -1.16 & -.06 & -.13 \\
\hline & $(.83)$ & $(.83)$ & $(.25)$ & $(.16)$ & $(.05)$ & $(.03)$ \\
\hline Referee fixed effects & Yes & Yes & Yes & Yes & Yes & Yes \\
\hline$t$-test: $\beta^{\text {Home }}=\beta^{\text {Away }}$ & \multirow{2}{*}{\multicolumn{2}{|c|}{$\begin{array}{l}t=3.91 \\
(0.000)\end{array}$}} & \multirow{2}{*}{\multicolumn{2}{|c|}{$\begin{array}{l}t=1.96 \\
(0.057)\end{array}$}} & \multirow{2}{*}{\multicolumn{2}{|c|}{$\begin{array}{l}t=1.71 \\
(0.095)\end{array}$}} \\
\hline$p$-value within parenthesis & & & & & & \\
\hline $\mathrm{R}^{2}$ & 0.1120 & 0.1076 & 0.1106 & 0.0975 & 0.0704 & 0.0802 \\
\hline Number of observations & 578 & 578 & 582 & 582 & 582 & 582 \\
\hline
\end{tabular}

Note: Standard errors clustered at the level of referee.

Table 4. Behavior of the referee regarding the away and home teams controlling for home and away team fixed effects

\begin{tabular}{|c|c|c|c|c|c|c|}
\hline & \multicolumn{2}{|c|}{ Fouls } & \multicolumn{2}{|c|}{ Yellow cards } & \multicolumn{2}{|c|}{ Red cards } \\
\hline \multirow{3}{*}{ No spectators } & Home team & Away team & Home team & Away team & Home team & Away team \\
\hline & 2.29 & -2.27 & -.52 & -1.13 & -.06 & -.14 \\
\hline & (.69) & $(.96)$ & $(.25)$ & $(.25)$ & $(.06)$ & $(.06)$ \\
\hline Referee fixed effects & Yes & Yes & Yes & Yes & Yes & Yes \\
\hline Home team fixed effects & Yes & Yes & Yes & Yes & Yes & Yes \\
\hline Away team fixed effects & Yes & Yes & Yes & Yes & Yes & Yes \\
\hline$t$-test: $\beta^{\text {Home }}=\beta^{\text {Away }}$ & \multirow{2}{*}{\multicolumn{2}{|c|}{$\begin{array}{l}t=3.76 \\
(0.001)\end{array}$}} & \multirow{2}{*}{\multicolumn{2}{|c|}{$\begin{array}{l}t=1.89 \\
(0.066)\end{array}$}} & \multirow{2}{*}{\multicolumn{2}{|c|}{$\begin{array}{l}t=1.64 \\
(0.108)\end{array}$}} \\
\hline & & & & & & \\
\hline $\mathrm{R}^{2}$ & 0.3596 & 0.3953 & 0.3302 & 0.3007 & 0.2145 & 0.2083 \\
\hline Number of observations & 578 & 578 & 582 & 582 & 582 & 582 \\
\hline
\end{tabular}

Note: Standard errors clustered at the level of referee. 
Table 5. Serie A. Behavior of the referee regarding the away and home teams

\begin{tabular}{|c|c|c|c|c|c|c|}
\hline & \multicolumn{2}{|c|}{ Fouls } & \multicolumn{2}{|c|}{ Yellow cards } & \multicolumn{2}{|c|}{ Red cards } \\
\hline \multirow{3}{*}{ No spectators } & Home team & Away team & Home team & Away team & Home team & Away team \\
\hline & 2.29 & -2.63 & .15 & -.96 & -.14 & -.18 \\
\hline & (1.34) & $(1.54)$ & $(.54)$ & $(.24)$ & $(.05)$ & $(.09)$ \\
\hline Referee fixed effects & Yes & Yes & Yes & Yes & Yes & Yes \\
\hline t-test: $\beta^{\text {Home }}=\beta^{\text {Away }}$ & \multicolumn{2}{|c|}{$\begin{array}{l}t=2.67 \\
(0.011)\end{array}$} & \multicolumn{2}{|c|}{$\begin{array}{l}t=1.54 \\
(0.131)\end{array}$} & \multicolumn{2}{|c|}{$\begin{array}{l}t=2.03 \\
(0.050)\end{array}$} \\
\hline $\mathrm{R}^{2}$ & 0.1200 & 0.1383 & 0.1541 & 0.1461 & 0.1197 & 0.1680 \\
\hline Number of observations & 277 & 277 & 277 & 277 & 277 & 277 \\
\hline
\end{tabular}

Note: Standard errors clustered at the level of referee.

Table 6. Serie B. Behavior of the referee regarding the away and home teams

\begin{tabular}{|c|c|c|c|c|c|c|}
\hline & \multicolumn{2}{|c|}{ Fouls } & \multicolumn{2}{|c|}{ Yellow cards } & \multicolumn{2}{|c|}{ Red cards } \\
\hline & Home team & Away team & Home team & Away team & Home team & Away team \\
\hline \multirow{2}{*}{ No spectators } & 1.31 & -2.37 & -.74 & -1.35 & -.08 & -.12 \\
\hline & $(1.00)$ & $(1.22)$ & $(.31)$ & $(.26)$ & $(.08)$ & $(.06)$ \\
\hline Referee fixed effects & Yes & Yes & Yes & Yes & Yes & Yes \\
\hline t-test: $\beta^{\text {Home }}=\beta^{\text {Away }}$ & \multicolumn{2}{|c|}{$\begin{array}{l}t=2.74 \\
(0.009)\end{array}$} & \multicolumn{2}{|c|}{$\begin{array}{l}t=1.37 \\
(0.177)\end{array}$} & \multicolumn{2}{|c|}{$\begin{array}{c}t=1.25 \\
(0.219)\end{array}$} \\
\hline $\mathrm{R}^{2}$ & 0.1909 & 0.1746 & 0.1734 & 0.1366 & 0.1292 & 0.1482 \\
\hline Number of observations & 301 & 301 & 305 & 305 & 305 & 305 \\
\hline
\end{tabular}

Note: Standard errors clustered at the level of referee. 


\title{
CESifo Working Paper Series
}

\author{
(for full list see www.cesifo-group.de)
}

1900 Tomer Blumkin and Efraim Sadka, On the Desirability of Taxing Charitable Contributions, January 2007

1901 Frederick van der Ploeg and Reinhilde Veugelers, Higher Education Reform and the Renewed Lisbon Strategy: Role of Member States and the European Commission, January 2007

1902 John Lewis, Hitting and Hoping? Meeting the Exchange Rate and Inflation Criteria during a Period of Nominal Convergence, January 2007

1903 Torben M. Andersen, The Scandinavian Model - Prospects and Challenges, January 2007

1904 Stephane Dees, Sean Holly, M. Hashem Pesaran and L. Vanessa Smith, Long Run Macroeconomic Relations in the Global Economy, January 2007

1905 Richard Jong-A-Pin and Jakob De Haan, Political Regime Change, Economic Reform and Growth Accelerations, January 2007

1906 Sascha O. Becker and Peter H. Egger, Endogenous Product versus Process Innovation and a Firm's Propensity to Export, February 2007

1907 Theo S. Eicher, Chris Papageorgiou and Oliver Roehn, Unraveling the Fortunates of the Fortunate: An Iterative Bayesian Model Averaging (IBMA) Approach, February 2007

1908 Liliana E. Pezzin, Robert A. Pollak and Barbara S. Schone, Efficiency in Family Bargaining: Living Arrangements and Caregiving Decisions of Adult Children and Disabled Elderly Parents, February 2007

1909 Christian Keuschnigg and Soren Bo Nielsen, Self-Selection and Advice in Venture Capital Finance, February 2007

1910 Rune Jansen Hagen and Gaute Torsvik, Irreversible Investments, Dynamic Inconsistency and Policy Convergence, February 2007

1911 Eric A. Hanushek and Ludger Woessmann, The Role of School Improvement in Economic Development, February 2007

1912 Bernard M. S. van Praag, Perspectives from the Happiness Literature and the Role of New Instruments for Policy Analysis, February 2007

1913 Volker Grossmann and Thomas M. Steger, Growth, Development, and Technological Change, February 2007 
1914 Margarita Katsimi and Thomas Moutos, Human Capital and the Feldstein-Horioka Puzzle, February 2007

1915 Oliver Roehn, Theo S. Eicher and Thomas Strobel, The Ifo Industry Growth Accounting Database, February 2007

1916 Ian Babetskii, Aggregate Wage Flexibility in Selected New EU Member States, February 2007

1917 Burkhard Heer, Alfred Maussner and Paul D. McNelis, The Money-Age Distribution: Empirical Facts and Limited Monetary Models, February 2007

1918 Yin-Wong Cheung, Menzie D. Chinn and Eijii Fujii, The Overvaluation of Renminbi Undervaluation, February 2007

1919 Jim Malley, Apostolis Philippopoulos and Ulrich Woitek, To React or Not? Fiscal Policy, Volatility and Welfare in the EU-3, February 2007

1920 Mattias Polborn, Competing for Recognition through Public Good Provision, February 2007

1921 Lars P. Feld and Benno Torgler, Tax Morale after the Reunification of Germany: Results from a Quasi-Natural Experiment, February 2007

1922 Robert S. Chirinko and Huntley Schaller, Fundamentals, Misvaluation, and Investment: The Real Story, February 2007

1923 Benno Torgler and Friedrich Schneider, Shadow Economy, Tax Morale, Governance and Institutional Quality: A Panel Analysis, February 2007

1924 Adrian Pagan and M. Hashem Pesaran, On Econometric Analysis of Structural Systems with Permanent and Transitory Shocks and Exogenous Variables, February 2007

1925 Hans-Werner Sinn, The Welfare State and the Forces of Globalization, February 2007

1926 Michael Smart, Raising Taxes through Equalization, February 2007

1927 Øystein Foros, Kåre P. Hagen and Hans Jarle Kind, Price-Dependent Profit Sharing as an Escape from the Bertrand Paradox, February 2007

1928 Balázs Égert, Kirsten Lommatzsch and Amina Lahrèche-Révil, Real Exchange Rates in Small Open OECD and Transition Economies: Comparing Apples with Oranges?, February 2007

1929 Aleksander Berentsen and Cyril Monnet, Monetary Policy in a Channel System, February 2007

1930 Wolfgang Ochel, The Free Movement of Inactive Citizens in the EU - A Challenge for the European Welfare State?, February 2007 
1931 James K. Hammitt and Nicolas Treich, Statistical vs. Identified Lives in Benefit-Cost Analysis, February 2007

1932 Wilhelm Kohler, The Bazaar Effect, Unbundling of Comparative Advantage, and Migration, February 2007

1933 Karsten Staehr, Fiscal Policies and Business Cycles in an Enlarged Euro Area, February 2007

1934 Michele Bernasconi and Paola Profeta, Redistribution or Education? The Political Economy of the Social Race, March 2007

1935 Axel Dreher, Martin Gassebner and Lars-H. R. Siemers, Does Terror Threaten Human Rights? Evidence from Panel Data, March 2007

1936 Naércio Aquino Menezes Filho and Marc-Andreas Muendler, Labor Reallocation in Response to Trade Reform, March 2007

1937 Gebhard Flaig and Timo Wollmershaeuser, Does the Euro-zone Diverge? A Stress Indicator for Analyzing Trends and Cycles in Real GDP and Inflation, March 2007

1938 Michael Funke and Michael Paetz, Environmental Policy Under Model Uncertainty: A Robust Optimal Control Approach, March 2007

1939 Byeongchan Seong, Sung K. Ahn and Peter A. Zadrozny, Cointegration Analysis with Mixed-Frequency Data, March 2007

1940 Monika Bütler and Michel André Maréchal, Framing Effects in Political Decision Making: Evidence from a Natural Voting Experiment, March 2007

1941 Giacomo Corneo and Olivier Jeanne, A Theory of Tolerance, March 2007

1942 Qing Hong and Michael Smart, In Praise of Tax Havens: International Tax Planning and Foreign Direct Investment, March 2007

1943 Yin-Wong Cheung, Dickson Tam and Matthew S. Yiu, Does the Chinese Interest Rate Follow the US Interest Rate?, March 2007

1944 Panu Poutvaara and Mikael Priks, Unemployment and Gang Crime: Could Prosperity Backfire?, March 2007

1945 Burkhard Heer, On the Modeling of the Income Distribution Business Cycle Dynamics, March 2007

1946 Christoph A. Schaltegger and Lars P. Feld, Are Fiscal Adjustments less Successful in Decentralized Governments?, March 2007

1947 Giovanni Facchini, Marcelo Olarreaga, Peri Silva and Gerald Willmann, Substitutability and Protectionism: Latin America's Trade Policy and Imports from China and India, March 2007 
1948 C. Mirjam van Praag and Bernard M. S. van Praag, The Benefits of Being Economics Professor A (and not Z), March 2007

1949 Astrid Hopfensitz and Frans van Winden, Dynamic Choice, Independence and Emotions, March 2007

1950 Guglielmo Maria Caporale and Luis A. Gil-Alana, A Multivariate Long-Memory Model with Structural Breaks, March 2007

1951 Mattias Ganslandt and Keith E. Maskus, Wholesale Price Discrimination and Parallel Imports, March 2007

1952 Michela Redoano, Fiscal Interactions Among European Countries. Does the EU Matter?, March 2007

1953 Stefan C. Wolter, Rémy Hübschi and Matthias Müller, Push or Pull? An Empirical Analysis of the Demand for Individual Project Grants from the Swiss National Science Foundation, March 2007

1954 Scott Alan Carson, African-American and White Inequality in the American South: Evidence from the $19^{\text {th }}$ Century Missouri State Prison, March 2007

1955 Peter Egger, Marko Koethenbuerger and Michael Smart, Do Fiscal Transfers Alleviate Business Tax Competition? Evidence from Germany, March 2007

1956 Panu Poutvaara and Lars-H. R. Siemers, Smoking and Social Interaction, March 2007

1957 Stephan Danninger and Fred Joutz, What Explains Germany’s Rebounding Export Market Share?, March 2007

1958 Stefan Krasa and Mattias Polborn, Majority-efficiency and Competition-efficiency in a Binary Policy Model, March 2007

1959 Thiess Buettner and Georg Wamser, Intercompany Loans and Profit Shifting Evidence from Company-Level Data, March 2007

1960 Per Pettersson-Lidbom and Mikael Priks, Behavior under Social Pressure: Empty Italian Stadiums and Referee Bias, April 2007 